M.Zh. Burkeyev ${ }^{1}$, E.M. Tazhbayev ${ }^{1}$, S.Zh. Davrenbekov ${ }^{1}$, A.A. Bakibayev², A.T. Kazhmuratova ${ }^{1}$, T.O. Khamitova ${ }^{1}$, L.T. Ibrayeva ${ }^{1}$, G.E. Kozhabekova ${ }^{1}$, Zh.A. Tolendi ${ }^{1}$, Zh.K. Imanbekova ${ }^{1}$

${ }^{I}$ Ye.A. Buketov Karaganda State University, Kazakhstan;

${ }^{2}$ National Research Tomsk State University, Russia (E-mail: 151194@mail.ru)

\title{
Selection of optimal conditions for obtaining of Co nanoparticles in the matrix of polymeric hydrogels
}

\begin{abstract}
Results of the influence of external factors on process of immobilization of metal nanoparticles on copolymers based on unsaturated polyester resins with unsaturated carboxylic acids were considered in the article. The effects of concentration of cobalt chloride solutions and distribution of metal particles by sizes in the matrix were studied. Results showed that increasing of cobalt concentration in solution shifts the equilibrium towards the formation of larger particles, i.e. there is a tendency to flocculation and formation of bi- and polymodal dispersions. The dependence of the dispersion formed at reduction of metal containing particles on the reducing agent and its concentration were researched. Potassium hypophosphite and sodium tetrahydroborate were used as reducing agents. It was found that upon reduction by sodium tetrahydroborate of cobalt nanoparticles have larger sizes than by using potassium hypophosphite.
\end{abstract}

Keywords: polyethylene glycol maleate, polypropylene glycol maleate, unsaturated polyester resins, catalysis, nanoparticles, reducing agent, catalyst, metal-polymeric complex, polymer matrix, electrocatalytic hydrogenation.

Catalytic hydrogenation is one of the most important processes of chemical industry, used for the reduction of organic compounds. Heterogeneous catalysts such as of palladium, platinum, etc. are traditionally used in industries. In order to economize nickel, cobalt, iron, copper, etc. may be used, but they have low activity and selectivity. Therefore the reactions, in their presence of these metals are mainly under rigid conditions. It is difficult to separate the homogeneous catalysts from the reaction products and use again. Thus it is important to produce catalysts possessing of both homogeneous and heterogeneous properties, namely high activity, selectivity and stability.

Incorporation of nanostructured metals in polymer matrix is one of the main directions of such a catalytically active, high-quality and low-cost catalysts creation and they are called metal-polymer or hybrid catalysts. Polymer nanocomposites contain the polymer matrix with distributed therein nanoparticles or nanofillers, which may be in spherical, flat or fiber structure. In recent years polymeric nanocomposites are especially in demand therefore a lot of different types of nanofillers enhancing and changing the properties of the initial polymers were developed. Total compatibility of base material with nanoparticles (NPs) added to it is general procedure for obtaining polymeric nanocomposites. However, it is important to properly distribute nanoparticles in the polymer for the final result.

Recovery of macrosize metals metals in swollen copolymers is not effective and subsequently NPs of Co were used. The largest part of atoms is beyond boundary of planar surface and has higher catalytic activity due to the small size of particles. This technology is relevant in electrocatalytic hydrogenation and also in many other fields such as the creation of non-linear optical element, laser systems, communication devices, structures with nanometer geometry for recording information, the transformation of radiations of different energy.

Nano-, micro- and nonionic, anionic, cationic and amphoteric characters macroporouse hydrogels are perspective and scantily explored polymeric matrixes for immobilization of metals NPs. It allows economizing the expensive and rare materials. The special properties of metal nanoparticles enhance catalytic activity that gives the possibility to catalyzing of reactions which impossible to carry out with those metals in the original amount.

Before to discussing the results for polydispersity of the metal nanoparticles, we describe what steps preceded it. Firstly, unsaturated polyester resins (UPR) were synthesized which molar mass was controlled by the synthesis conditions and reaction time. UPR were obtained with a molar mass of 1500-4000. Further, copolymerization reactions with acrylic acid(AA) and metacrylic acid(MAA) at different initial ratios of those comonomers were carried out. Scheme of copolymerization of UPR with acrylic acids is follows. 


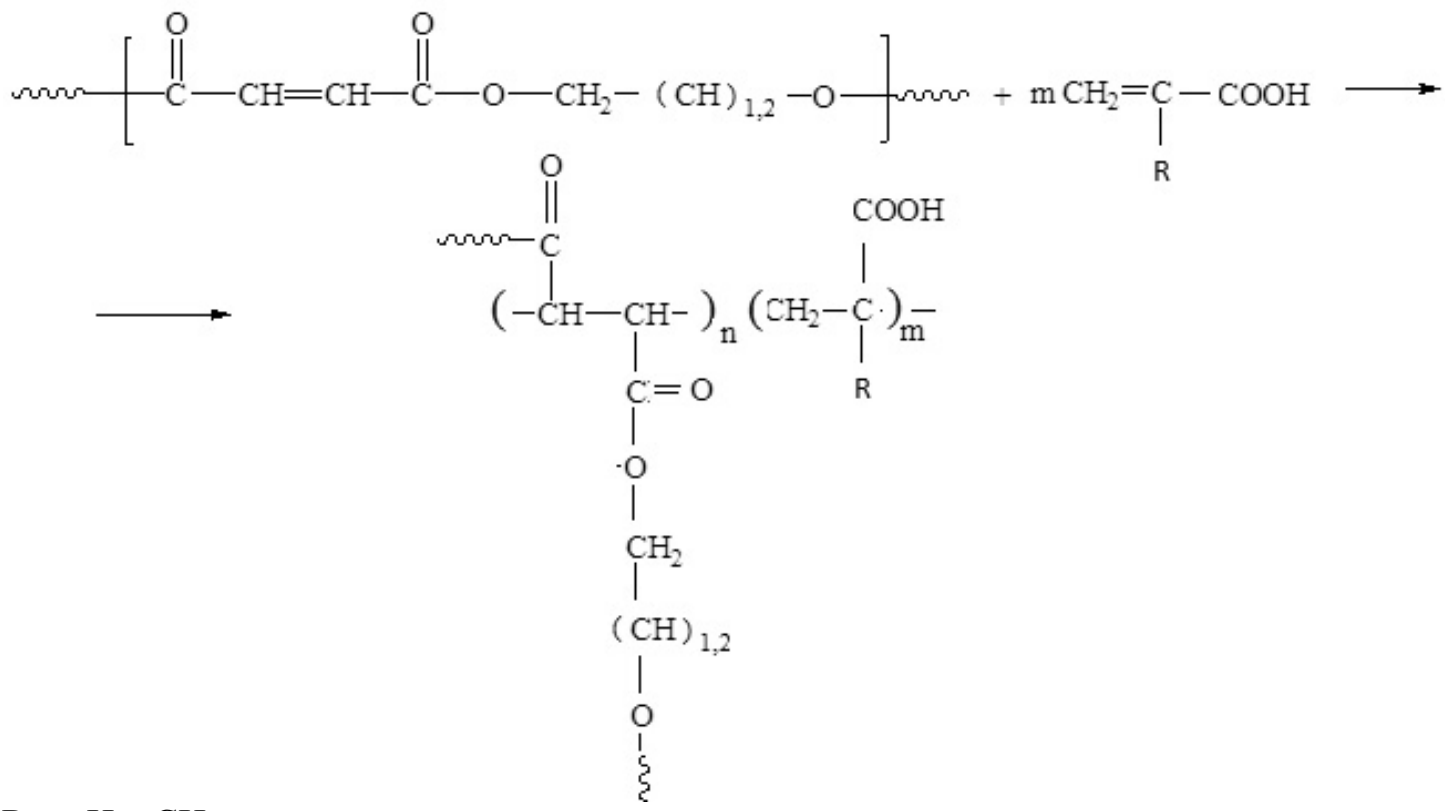

where $\mathrm{R}=-\mathrm{H},-\mathrm{CH}_{3}$.

Then the copolymer is placed in a metal salt solution from which restored using various reducing agents. In that way the metal particles were immobilized in a polymer grid i.e. metal-polymer composite was produced.

Let us consider each stage from the viewpoint of metal particles dispersion. The production conditions were varied in order to select the optimal conditions for producing cobalt nanoparticles in the polymer matrix. Table 1 shows the experimental results on the influence of $\mathrm{CoCl}_{2}$ concentration on size and polydispersity of the metal nanoparticles. The data were obtained by photon correlation spectroscopy instrument Malvern Zetasizer Nano S90. In the final product content of Co nanoparticles rises with the increasing $\mathrm{CoCl}_{2}$ concentration in solution to a certain value, but the actual yield is reduced a bit [1-3].

$\mathrm{Tab}$ a 1

Effect of concentration $\mathrm{CoCl}_{2}$ on size and polydispersity of metal nanoparticles

\begin{tabular}{|c|c|c|c|c|c|c|}
\hline Copolymer & $\begin{array}{c}\text { Composi- } \\
\text { tion }\end{array}$ & $\begin{array}{c}\text { Concentration } \\
\text { of } \mathrm{CoCl}_{2} \text { in solu- } \\
\text { tion, } \mathrm{N}\end{array}$ & $\begin{array}{c}\text { Concentration } \\
\text { of ammonia solution } \\
\text { of } \mathrm{AgCl}, \mathrm{N}\end{array}$ & $\begin{array}{c}\text { Yield } \\
\text { of nanoparti- } \\
\text { cles, } \% \\
\end{array}$ & $\begin{array}{l}\text { Size of } \mathrm{Co}^{0} \\
\text { particle, } \mathrm{nm}\end{array}$ & Polydispersity \\
\hline \multirow{3}{*}{$\begin{array}{l}\text { Polyethylene } \\
\text { glycol maleinate } \\
\text { (p-EGM:MAA) } \\
(18.22: 81.78 \\
\text { mass. } \%)\end{array}$} & 1 & 0.05 & $0.1 \cdot 10^{-3}$ & $82 \pm 1,1$ & $310 \pm 15$ & 0.125 \\
\hline & 2 & 0.10 & $0.2 \cdot 10^{-3}$ & $80 \pm 1$ & $315 \pm 17$ & 0.184 \\
\hline & 3 & 0.20 & $0.4 \cdot 10^{-3}$ & $54 \pm 0,5$ & $445 \pm 22$ & 0.750 \\
\hline
\end{tabular}

Cobalt chloride solution with of $0.1 \mathrm{~N}$ concentrations is optimal for the case when a satisfactory combination of the yield of metal particles, particle size and polydispersity is achieved. The catalyst concentration doesn't have essential influence on the properties of the final product. Perhaps the changes will affect the kinetics of the process that are studied and regulated at the following stages.

Similar results were obtained for the systems: copolymer of UPR with AA and MAA with cobalt. Thus we obtained the cobalt nanoparticles with an average particle diameter of $180 \pm 2.3 \mathrm{~nm}$ for p-EGM:AA and $300 \pm 1.5 \mathrm{~nm}$ for polypropylene glycol maleinate (p-PGM):MAA (Fig. 1, 2) by using samples of more crosslinked polymers as matrixes. 


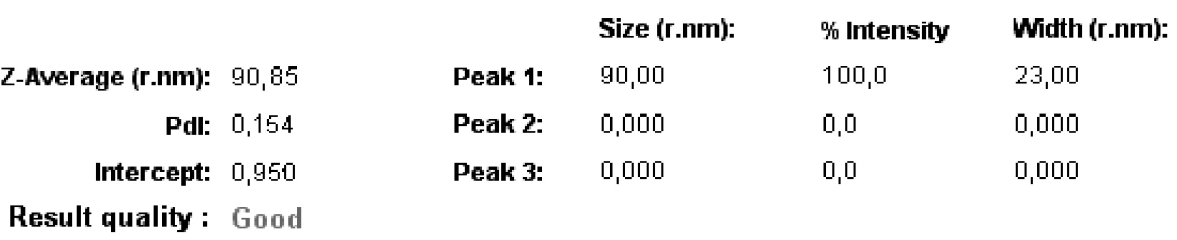

Size Distribution by Intensity

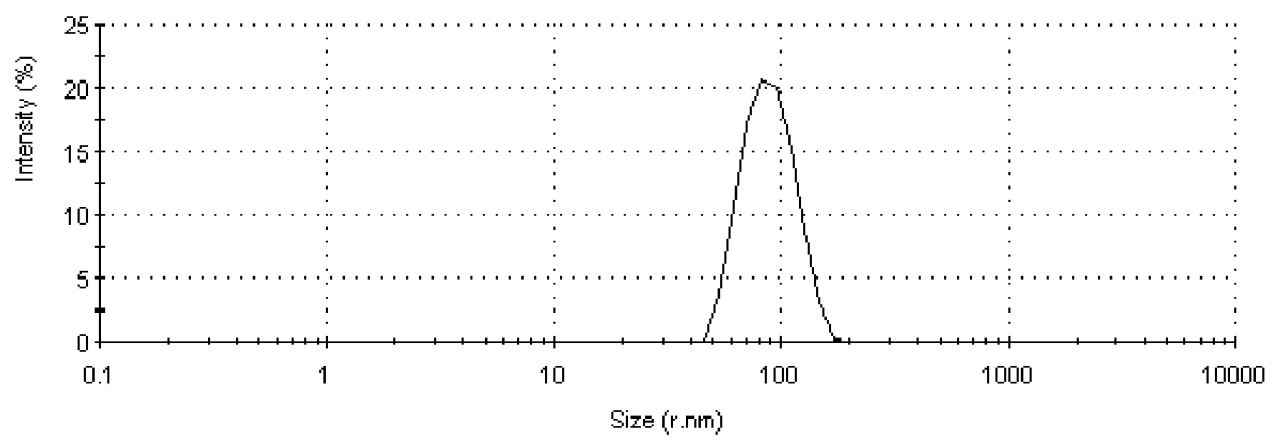

Figure 1. Distribution of cobalt nanoparticles on the basis of EGM:AA copolymer

$\begin{array}{rllcl} & & \text { Size (d.nm): } & \text { \% Intensity } & \text { Width (d.nm): } \\ \text { Z-Average (d.nm): } 305,02 & \text { Peak 1: } & 306,4 & 100,0 & 16,04 \\ \text { Pdl: } 0,385 & \text { Peak 2: } & 0,000 & 0,0 & 0,000 \\ \text { Intercept: } 0,360 & \text { Peak 3: } & 0,000 & 0,0 & 0,000 \\ \text { Result quality : Good } & & & & \end{array}$

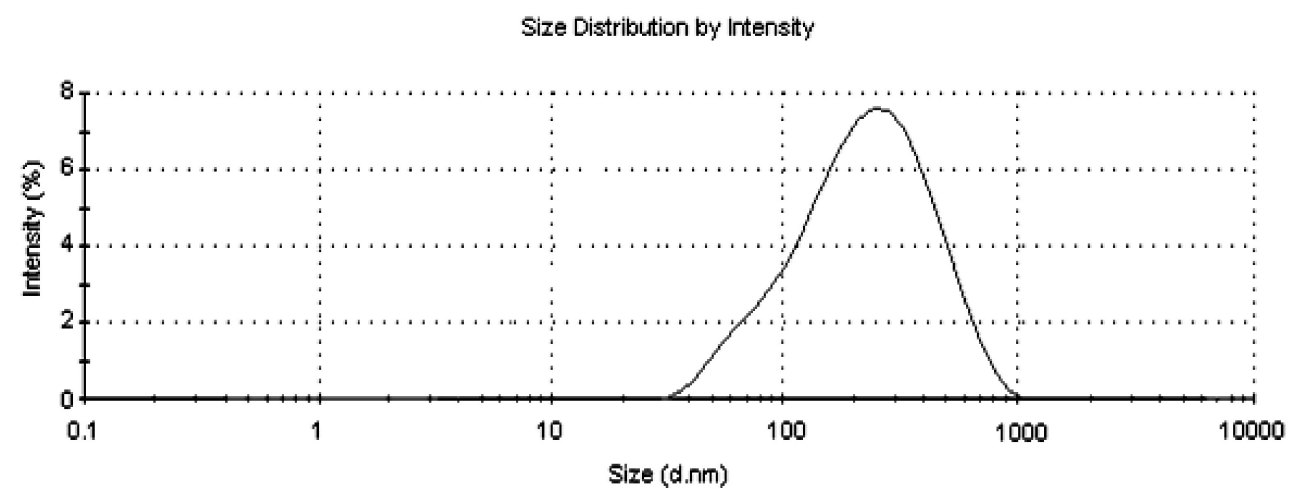

Figure 2. Distribution of cobalt nanoparticles on the basis of PGM:MAA copolymer

Electron Microscopy results confirm the data obtained by photon correlation spectroscopy. Histograms of numerical distribution by sizes of Co nanoparticles, after their matrix synthesis in the volume of polymer gel based on of UPR and AA (MAA) were plotted, using the results of microscopic studies by the procedure (Fig. 3) $[4,5]$.

The results indicate that relatively uniform particle size distribution is observed in the gel volume. Thus, increasing Co concentration shifts the equilibrium towards the formation of larger particles, i.e. there is a tendency to flocculation and the formation of bi- and multimodal dispersed systems. Nature and concentration of the reducing agent deeply influence on the dispersion of formed metal particles at recovery. Therefore, for comparison, we use reducing agent such as sodium hypophosphite and potassium tetrahydroborate, which are of great practical importance and used for a wide range of metals recovery. Synthesis of cobalt NSP was carried by chemical reduction of metal ions from the salt solution [6, 7]. 

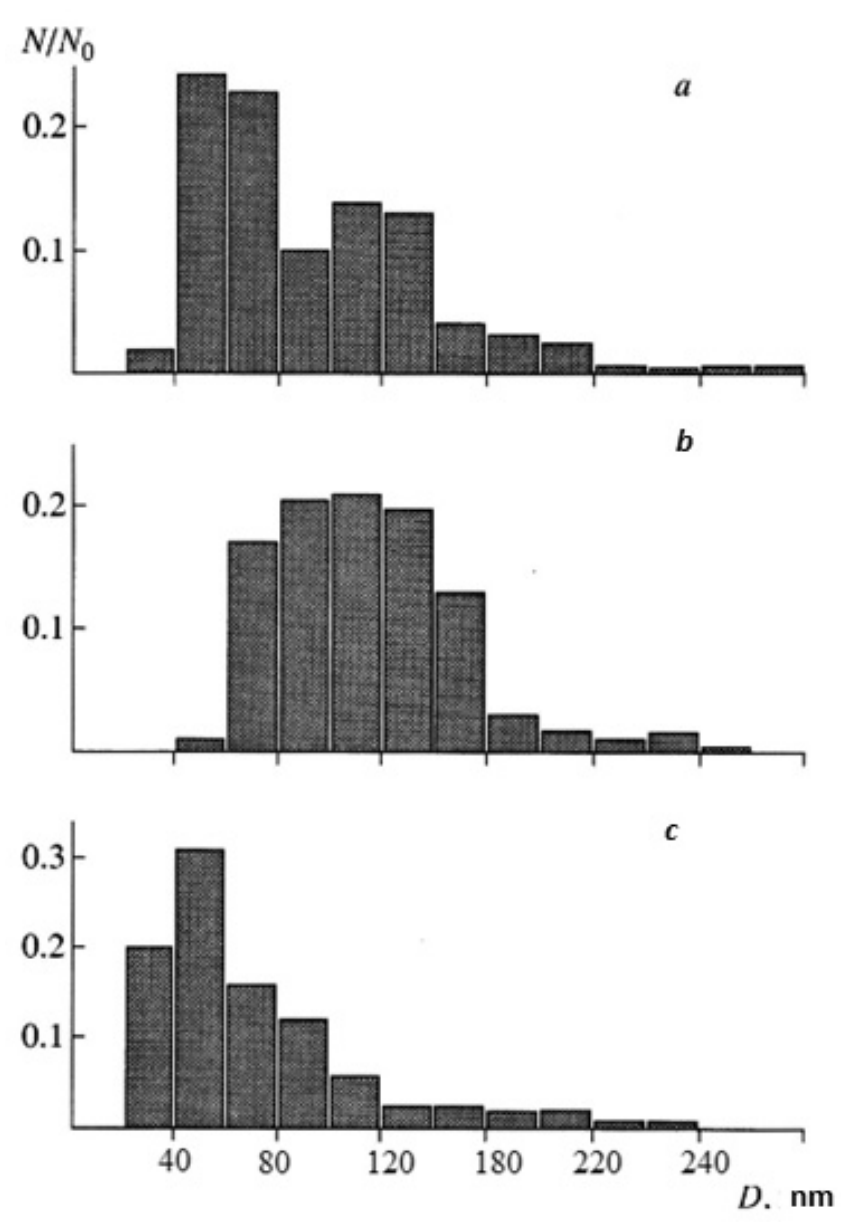

$$
a-\mathrm{p}-\mathrm{PGM}-\mathrm{AA} ; b-\mathrm{p}-\mathrm{EGM}-\mathrm{AA} ; c-\mathrm{p}-\mathrm{EGM}-\mathrm{MAA}
$$

Figure 3. The content of Co particles in the MPC

Microphotographs of metal-polymer composites obtained at recovering by various reducing agents are shown in Figure 4.

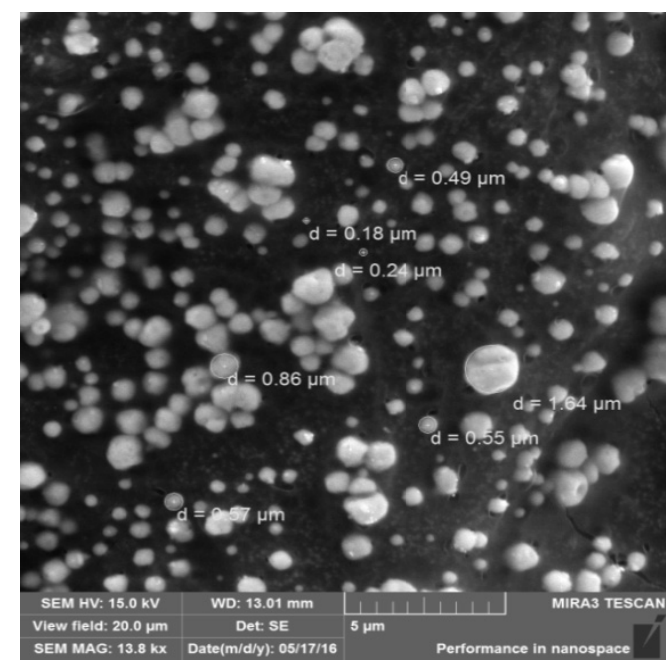

1

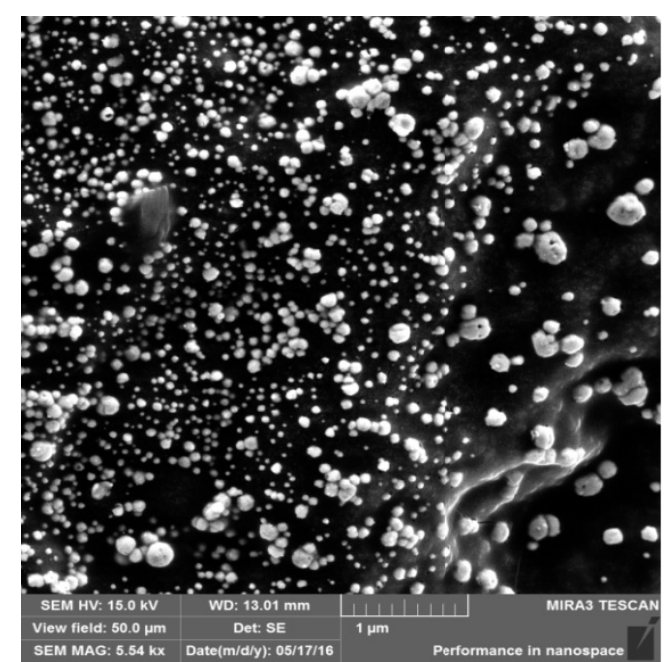

2

Figure 4. Electron microscopic images of the MPC with immobilized nanoparticles of Co at recovering by $\mathrm{NaBH}_{4}(1)$ and $\mathrm{KH}_{2} \mathrm{PO}_{2} \cdot \mathrm{H}_{2} \mathrm{O}(2)$ 
It is seen from the electronic images, the metal nanoparticles have a larger size when used as a reducing agent of $\mathrm{NaBH}_{4}$ than $\mathrm{KH}_{2} \mathrm{PO}_{2}$. Thus, the reduction of cobalt ions by potassium hypophosphite and sodium tetrahydroborate metal cobalt particle sizes are 50-100 and 500-600 nm, respectively. Alkaline medium, which was maintained by addition of ammonia solution (to $\mathrm{pH} 8.5$ ) also contributed to swelling polymer grid and immobilizing metals in pores $[8,9]$. Table 2 shows content and the particle size of Co in polymer hydrogels on the basis of UPR.

Table 2

\section{Sizes and content of Co nanoparticles}

\begin{tabular}{|c|c|c|}
\hline Reducing agent, $\mathrm{M}$ & Sizes of $\mathrm{Co}^{0}$ particle, $\mathrm{nm}$ & Content of $\mathrm{Co}^{0}, \mathrm{~kg} / \mathrm{m}^{2}$ \\
\hline \multicolumn{3}{|c|}{ Reducing agent $\mathrm{NaBH}_{4}$, redox potential -1.24 to $0.48 \mathrm{~V}$} \\
\hline $5 * 10^{-3}$ & $\begin{array}{c}620 \\
614 \\
623 \\
\text { Average } 619 \pm 4\end{array}$ & 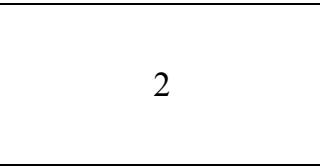 \\
\hline $1 * 10^{-3}$ & $\begin{array}{c}500 \\
520 \\
510 \\
\text { Average } 510 \pm 10\end{array}$ & 2 \\
\hline \multicolumn{3}{|c|}{ Reducing agent $\mathrm{KH}_{2} \mathrm{PO}_{2} \cdot \mathrm{H}_{2} \mathrm{O}$, redox potential -0.5 to $-1.57 \mathrm{~V}$} \\
\hline $5 * 10^{-3}$ & $\begin{array}{c}100 \\
105 \\
125 \\
\text { Average } 110 \pm 15\end{array}$ & 1 \\
\hline $1 * 10^{-3}$ & $\begin{array}{c}50 \\
48 \\
55 \\
\text { Average } 51 \pm 4\end{array}$ & 11 \\
\hline
\end{tabular}

Since $\mathrm{NaBH}_{4}$ is a stronger reducing agent the reaction of formation of cobalt particles occurs at highrate with formation of larger particles. Recovery of smaller cobalt NPs by $\mathrm{KH}_{2} \mathrm{PO}_{2} \cdot \mathrm{H}_{2} \mathrm{O}$ proceeds rather easily but in the presence of an ammonia solution of silver chloride. At the same time large difference between the redox potential of the reducing agent and the recovered metal is important for obtaining highly dispersive metal particles [10].

The quantitative composition of the resulting cobalt metal in the polymer matrix volume was determined on the atomic absorption spectrometer AA 140 Varian (USA). These data are also confirmed by the results of atomic - emission spectroscopy (Fig. 5).

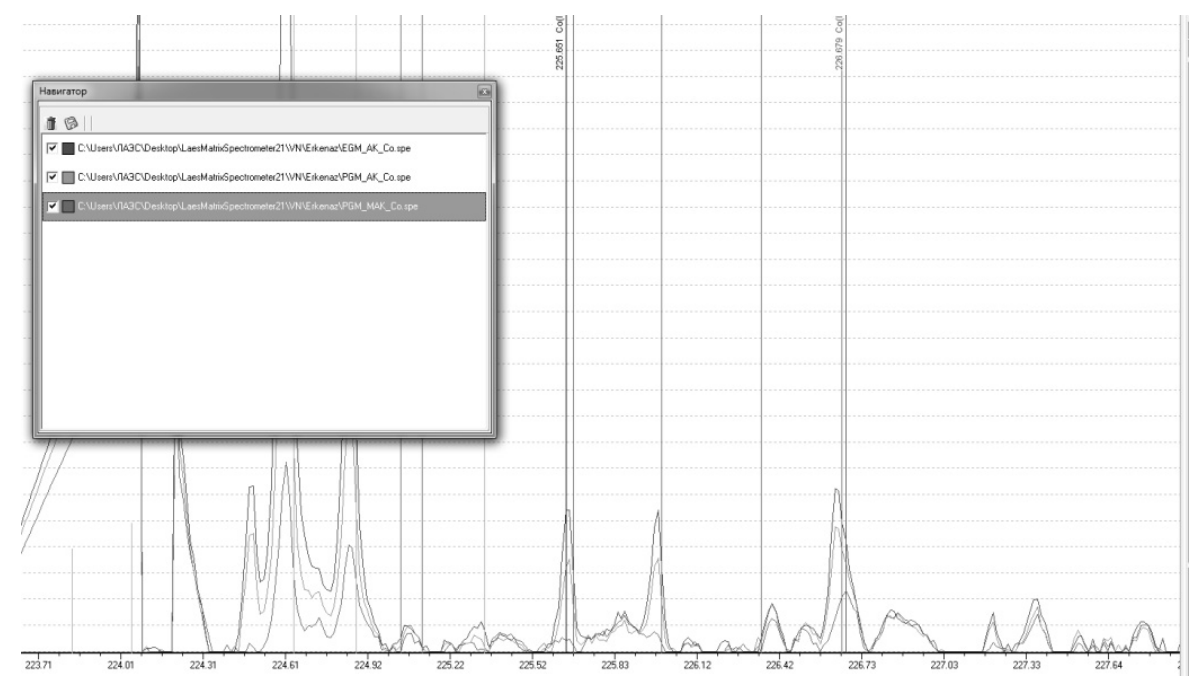

Figure 5. A composition analysis the UPR on the laser atomic-emission spectrometer Matrix Continuum 
According to the FTIR-spectra of copolymers p-EGM:AA, MAA and p-PGM:AA, MAA there is no intense absorption band at $1670 \mathrm{~cm}^{-1}$, corresponding to vibrations of unreacted double bonds. There are intense absorption band at $1157 \mathrm{~cm}^{-1}$, corresponding ether bond vibrations. Vibrations of the methyl groups of methacrylic acid $2926 \mathrm{~cm}^{-1}$, carboxyl groups, providing swelling appear in the $1723 \mathrm{~cm}^{-1}$. Absorption bands of MPC carboxyl groups are shift towards higher wavelengths $\left(2-4 \mathrm{~cm}^{-1}\right)$ perhaps bathochromic shift is determined by the formation of non-chemical bonds between the polymer molecules and metal (cobalt).

Thus, on the basis of the above, we can draw the following conclusions:

1. The increasing of cobalt concentration in solution displaces the equilibrium towards the formation of larger particles, i.e. there is a tendency to flocculation and the formation of bi- and polymodal dispersions.

2. NPs of cobalt have larger sizes upon reduction by sodium tetrahydroborate than by using potassium hypophosphite.

\title{
References
}

1 Papisov, I.M., Jablokov, Y.S., Prokofiev, A.I., \& Litmanovich, A.A. (1993). Makromolekuly kak regulatory processa formirovaniia malyh chastic metalla pri vosstanovlenii nikelya (II) v gidrogele interpolimernogo kompleksa [Macromolecules as regulators of the formation of small metal particles in the reduction of nickel (II) in the hydrogel interpolymer complex]. Makromol. Komp. - Macromol. Comp., A. 35, 5, 515-519 [in Russian].

2 Litmanovich, O.Yu., Bogdanov, A.G., Litmanovich, A.A., \& Papisov, I.M. (1998). Uznavanie i zameshchenie vo vzaimodeistvijah makromolekul i nanochastic [Learning and replacement in the interactions of macromolecules and nanoparticles]. Vysokomol. soed. - Macromol. Comp., 40, 1, 100-101 [in Russian].

3 Tazhbayev, Ye.M., Burkeyev, M.Zh., Kazhmuratova, A.T., Sugralina, L.M., \& Zhaparova, L.Zh. (2007). Hydrogels of Copolymers of $\beta$-Vinyloxyethylamide of Acrylic Acid with Unsaturated Carboxylic Acids. Polymer Science Ser. B., 49, 3-4, $257-260$.

4 Wilcoxon, J.P., \& Abrams, B.L. (2006). Synthesis, structure and properties of metal nanoclusters. Chem. Soc. Rev., 35, 11621194.

5 Komori, T., \& Sakamoto, R. (1989). On Tanaka-Fillmore's kinetics swelling of gels. Colloid and Polym. Sci., 267, 2, 179183.

6 Fillipova, O.E. (2000). «Vospreimchivye» polimernye geli [«Receptive» polymeric gels] Vysokomolec. soed., Seriya C. High molecular compounds, Series C, 42, 12, 2328-2352 [in Russian].

7 Uchida, Makoto, Kurosawa, Miyuki, \& Osada, Yoshihito (1995). Swelling process and order-disorder transition of hydrogel containing hydrophobic ionizable groups. Macromolecules, 28, 4583-4586.

8 Tazhbayev, Ye.M., Kazhmuratova, A.T., Zhumagaliyeva, T.S., Tolendi, Zh.A., \& Kozhabekova, G.E. (2016). Creation of a polymeric matrix on the basis of polyester resins for an immobilization of metals nanoparticles, Bulletin of the Karaganda University. Series Chemistry, 3, 55-59.

9 Kataoka, Kazunori, Koyo, Hiroyuki, \& Tsuruta, Teiji (1995). Novel pH-sensitive hydrogels of segmented poly(amineureas) having a repetitive array of polar and apolar units in the main chain. Macromolecules, 28, 9, 3336-3341.

10 Pavlyuchenko, V.N., \& Ivanchev, S.S. (2009). Kompozicionnye polimernye gidrogeli [Composite polymer hydrogels] Vysokomolec. soed. - Macromol. Comp., 51, 7, 1075-1095 [in Russian].

\author{
М.Ж. Буркеев, Е.М. Тәжбаев, С.Ж. Давренбеков, А.А. Бәкибаев, А.Т. Қажмұратова, \\ Т.Ө. Хамитова, Л.Т. Ибраева, Г.Е. Қожабекова, Ж.А. Төленді, Ж.Қ. Иманбекова
}

\section{Полимерлі гидрогель матрицасындағы кобальт нанобөлшектерін алудың оңтайлы жағдайлары}

\begin{abstract}
Мақалада қанықпаған полиэфирлі шайырлар мен қанықпаған карбон қышқылдары негізіндегі сополимерлерге орнықтырылған наноөлшемді металл бөлшектеріне қоршаған орта факторларының әсері қарастырылған. Кобальт хлориді концентрациясының ықпалы, сонымен қатар матрицада металл бөлшектеріне қоршаған көлемдері бойынша таралуы зерттелген. Кобальт тұзының концентрациясының жоғарылауы үлкен көлемді бөлшектердің түзілуіне қарай тепе-теңдікті ығыстыратындығы, яғни флокуляция және би-, полимодальды дисперсті жүйелердің түзілу тенденциясы, байқалды. Металқұрамды бөлшектердің тотығуы кезінде түзілетін дисперстіліктің тотықтырғышқа және оның концентрациясына тәуелділігі зерттелді. Тотықтырғыш ретінде калий гипофосфиті және натрий тетрагидробораты қолданылды. Кобальттың наноөлшемді бөлшектерінің синтезі кезінде аталған тотықтырғыштардан натрийдің тетрогидробораты, калий гипофосфитіне қарағанда, металл бөлшектері үлкен көлемге ие екені байқалды.
\end{abstract}

Kiлm сөздер: полиэтиленгликольмалеинат, полипропиленгликольмалеинат, қанықпаған полиэфирлі шайырлар, катализ, нанобөлшектер, тотықтырғыш, катализатор, металл-полимерлі кешендер, полимерлі матрица, электрокаталитикалық гидрлеу. 
М.Ж. Буркеев, Е.М. Тажбаев, С.Ж. Давренбеков, А.А. Бакибаев, А.Т. Кажмуратова, Т.О. Хамитова, Л.Т. Ибраева, Г.Е. Кожабекова, Ж.А. Толенди, Ж.К. Иманбекова

\title{
Подбор оптимальных условий для получения наночастиц Со в матрице полимерного гидрогеля
}

\begin{abstract}
Рассмотрены результаты влияния внешних факторов на процесс иммобилизации наноразмерных частиц металлов в сополимеры на основе ненасыщенных полиэфирных смол с ненасыщенными карбоновыми кислотами. Изучено влияние концентрации растворов солей хлорида кобальта, а также распределение частиц металла по размерам в объеме матрицы. Установлено, что повышение концентрации кобальта смещает равновесие в сторону образования более крупных частиц, т.е. появляется тенденция к флокуляции и образованию би- и полимодальных дисперсных систем. Изучена зависимость дисперсности образующихся при восстановлении металлсодержащих частиц от восстановителя, а также его концентрации. В качестве восстановителей были использованы гипофосфит калия и тетрагидроборат натрия. При синтезе наноразмерных частиц кобальта можно отметить, что при использовании тетрагидробората натрия наночастицы металла имеют больший размер, чем при гипофосфите калия.
\end{abstract}

Ключевые слова: полиэтиленгликольмалеинат, полипропиленгликольмалеинат, ненасыщенная полиэфирная смола, катализ, наночастицы, восстановитель, катализатор, металлполимерный комплекс, полимерная матрица, электрокаталитическое гидрирование. 